\title{
ANALISIS KEPUASAN JAMAAH UMRAH TERHADAP PENERAPAN SISTEM PEMASARAN PENJUALAN LANGSUNG BERJENJANG SYARIAH PADA PT ARMINAREKA PERDANA
}

\author{
Indra Dwi Ariyono ${ }^{1}$, dan Adril Hakim²
}

\begin{abstract}
1 Program Studi Perbankan Syariah, Sekolah Tinggi Ekonomi Islam SEBI, Depok, Jawa Barat. Email: dwiindra.dwi@gmail.com

2 Program Studi Perbankan Syariah, Sekolah Tinggi Ekonomi Islam SEBI, Depok, Jawa Barat. Email: adrh272@yahoo.co.id
\end{abstract}

\begin{abstract}
ABSTRAK: Penelitian ini membahas tentang kepuasan jamaah umrah terhadap penerapan sistrem pemasaran PLBS yang diterapkan oleh PT. Arminareka Perdana seiring adanya fatwa DSN - MUI No. 83 / VI / 2012. Data yang digunakan dalam penelitian ini adalah data primer dengan wawancara menggunakan kuesioner. Jumlah sampel 103 responden jamaah umrah PT. Arminareka Perdana. Data dianalisis secara deskriptif untuk mengetahui tingkat kepuasan jamaah umrah terhadap sistem PLBS di PT. Arminareka Perdana.Hasil analisis ini mengungkapkan bahwa nilai kepuasan sebesar 0,76 (puas) pada variabel silent service, sebesar 0,86 (sangat puas) pada variabel image, sebesar 0,63 (puas) pada variabel proactive service, sebesar 0,79 (puas) pada variabel quality product dan sebesar 0,72 (puas) pada variabel pricing. Dapat disimpulkan bahwa 4 variabel bernilai puas dan 1 variabel bernilai sangat puas dengan nilai interpretasi 0,61-0,80 dan 0,81 $-1,00$.
\end{abstract}

\section{Kata Kunci : Jama'ah Umrah, PLBS, Fatwa dan Kepuasan pelanggan}

\begin{abstract}
This study discusses the satisfaction of Umrah pilgrims to the application of marketing system of PLBS applied by PT .Arminareka Perdana, as along with the emergence of fatwa DSN - MUI No. 83 / VI / 2012. The data used in this study are primary data from interviews using questionnaires. Data were analyzed descriptively to determine the level of satisfaction of Umrah pilgrims against PLBS system in PT. Arminareka Perdana. The result revealed that the satisfaction score is 0.76 (satisfied) in the variable silent service. Then it is 0.86 (very satisfied) in the variable image, and 0.63 (satisfied) in the variable proactive service, and before the last is 0.79 (satisfied) in the variable quality product and the last is 0.72 (satisfied) in the variable pricing. It can be concluded that the four variables worth satisfied and 1 variable is worth very satisfied with the value interpretation from 0.61 to 0.80 and from 0.81 to 1.00.
\end{abstract}

Keywords: Umroh pilgrims, PLBS, fatwa, and costumer satisfactory 
106 | Ariyono \& Hakim:Analisis Kepuasan Jamaah Umroh Terhadap Penerapan Sistem Pemasaran Penjualan Langsung...

\section{PENDAHULUAN}

alam dunia bisnis, kepuasan konsumen merupakan indikator keberhasilan dari produk yang diproduksi perusahaan. Suatu perusahaan ingin memberikan suatu kepuasan kepada konsumennya melalui produk - produknya entah berupa barang atau jasa. Kepuasan atau ketidakpuasan konsumen adalah respon terhadap evaluasi ketidaksesuaian atau diskonfirmasi yang dirasakan antara harapan sebelumnya dan kinerja aktual produk yang dirasakan setelah pemakaian (Tse dan Wilson dalam Nasution, 2004). Jeffrey Gitomer (1998) dalam bukunya yang berjudul Customer Satisfaction is Worthless, Customer Loyalty is Priceles mengatakan bahwa "It is customer not company who pays your paycheck!". Artinya pelanggan menjadi sumber pendapatan bagi perusahaan untuk menggaji karyawannya. Sehingga menjaga loyalitas pelanggan menjadi suiatu kewajiban perusahaan dengan memberikan pelayanan yang tidak hanya bagus namun harus luar biasa.

Pemasaran memiliki point $4 \mathrm{P}$ (Place, Price, Promotion dan Product). Fungsi pemasaran menempati proporsi yang sangat menentukan keberhasilan bisnis perusahaan tanpa mengesampingkan fungsi - fungsi bisnis lainnya. Dalam perkembangannya, penjualan langsung berjenjang mendapat sertifikat sebagai sistem pemasaran syariah dan DSN - MUI mengeluarkan fatwa mengenai sistem penjualan langsung berjenjang tersebut dengan fatwa N0. 83 / DSN - MUI / VII / 2012 tentang penjualan langsung berje njang syariah jasa perjalanan umrah. Semenjak adanya fatwa dari Dewan Syariah Nasional - Majelis Ulama Indonesia (DSN - MUI), maka sistem penjualan berjenjang yang memenuhi kriteria nilai - nilai syariah menjadi sistem penjualan langsung berjenjangsyariah.

PT. Arminareka Perdana (ARP) merupakan perusahaan yang bergerak dalam bidang penyelenggara perjalanan umrah dan haji plus yang berlokasi di Gedung Menara Salemba Lt.5, Jalan Salemba Raya No.05, Jakarta Pusat. Sistem pemasaran yang diterapkan PT Arminareka Perdana berupa sistem penjualan langsung berjenjang syariah. Sebagai contoh, bila Ali adalah seorang jamaah pertama yang mendaftar umrah di PT. Arminareka Perdana. Lalu Ali berhasil mengajak Usman dan Abu untuk umrah bersama di PT. Arminareka Perdana dan Ali mendapatkan komisi dari hasil kerjanya tersebut yang dinamakan referensi langsung. Kemudian Usman dan Abu melakukan hal yang sama dengan apa yang dilakukan Ali. Usman berhasil mengajak Fatimah untuk berangkat umrah dan Usman mendapatkan komisi hasil referensi langsung, dan Ali tidak mendapatkan komisi sama sekali karena Fatimah adalah hasil referensi dari Usman.

Gambar 1. 1 Model Pembagian Komisi PT. Arminareka Perdana

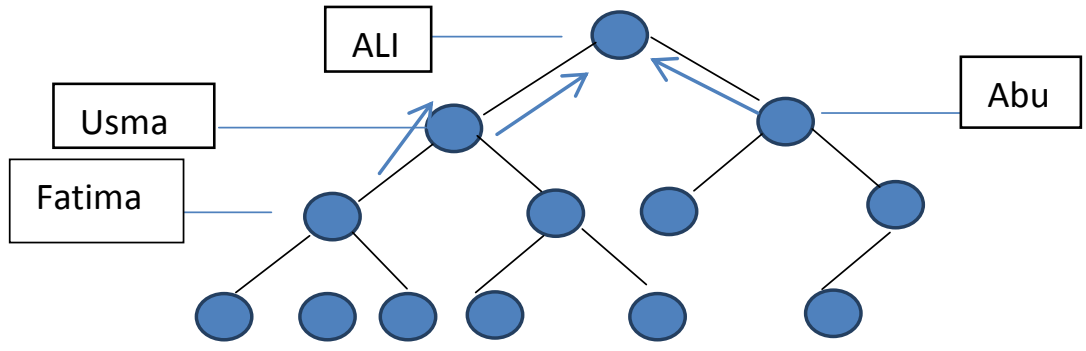

Sumber: data diolah 
Pemberian komisi ini didasarkan pada hadits Nabi riwayat Ibnu Majah dari Ibnu 'Umar yaitu : Diriwayatkan dari Ibnu 'Umar r.a, ia berkata, Rasulullah SAW bersabda : "Berikanlah upah pekerja sebelum keringatnya kering." (HR Ibnu Majah).

Kualitas jasa pelayanan yang baik dapat memberikan manfaat kepuasan bagi konsumen, diantaranya memberikan keyakinan yang kuat pada jasa layanan perusahaan sehingga terciptanya kesetiaan konsumen yang sering disebut sebagai loyalitas pelanggan. Loyalitas pelanggan yang tinggi menjadi faktor pendorong untuk pembelian ulang dan bahkan bisa merekomendasikan orang lain untuk menggunakan jasa tersebut. Berdasarkan pemaparan datas, penulis merasa perlu untuk melakukan penelitian tentang "Analisis Kepuasan Jamaah Umroh Terhadap Penerapan Sistem Pemasaran Penjualan Langsung Berjenjang Syariah Pada PT. Arminareka Perdana" agar memperoleh informasi yang lebih mendalam dan jelas yang disertai dengan fakta dan data ilmiah mengenai kepuasaan jamaah umroh ARP dengan diterapkannya sistem penjualan langsung berjenjang syariah tersebut. Untuk mengetahui tingkat kepuasan jamaah umrah terhadap sistem penjualan langsung berjenjang syariah sehingga jamaah umrah tetap loyal dan melakukan pemakaian ulang produk jasa ARP.

\section{TELAAH PUSTAKA}

\section{Kepuasan Konsumen}

\section{Definisi Konsumen}

Konsumen adalah seseorang, sekelompok orang, maupun organisasi dalam usaha mendapatkan, menggunakan dan mengambil keputusan dalam proses mengkonsumsi barang dan jasa (Sidjabat, 2014, hal. 29) Pelanggan atau konsumen menjadi fokus utama dalam penelitian ini. Guna mendapatkan informasi yang akurat tentang kepuasan konsumen, ada baiknya mengetahui cara konsumen membeli barang / jasa saat ini. Saat ini proses konsumen membeli melalui tahapan 5A. 5A yang dimaksud adalah aware, appeal, ask, act dan advocate (Kertajaya, 2014, hal. 21).

\section{Gambar 2. 1 Cara Konsumen Membeli Saat ini}

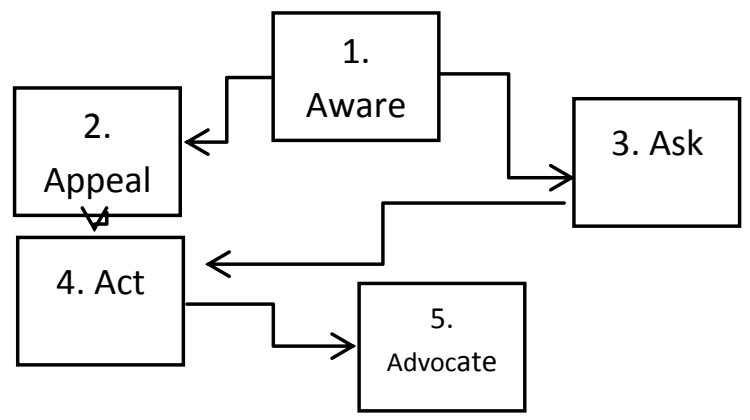

Sumber : Hermawan Kertajaya $(2014 ; 20)$

\section{Definisi Kepuasan}

Spreng, Mackenzie dan Olshavsky (1996;23) mengemukakan tentang kepuasan adalah pernyataan afektif tentang reaksi emosional terhadap pengalaman produk atau jasa yang dipengaruhi oleh afeksi pelanggan oleh produk tersebut. 
108 |Ariyono \& Hakim:Analisis Kepuasan Jamaah Umroh Terhadap Penerapan Sistem Pemasaran Penjualan Langsung...

Gambar 2. 2 Indikator - indicator Kepuasan Pelanggan

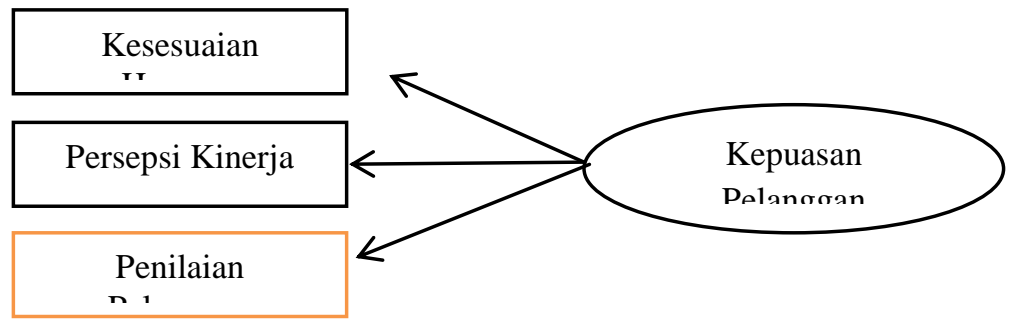

Sumber : Spreng, Mackenzie \& Olshavsky ( 1996 )

Terdapat konsep kepuasan yang direrangkan oleh Tjiptono (2006 ; 352) bahwa kepuasan pelanggan adalah titik bertemunya harapan pada suatu produk dengan nilai produk / jasa yang dihasilkan suatu perusahaan.

\section{Gambar 2. 3 Konsep Kepuasan Konsumen}
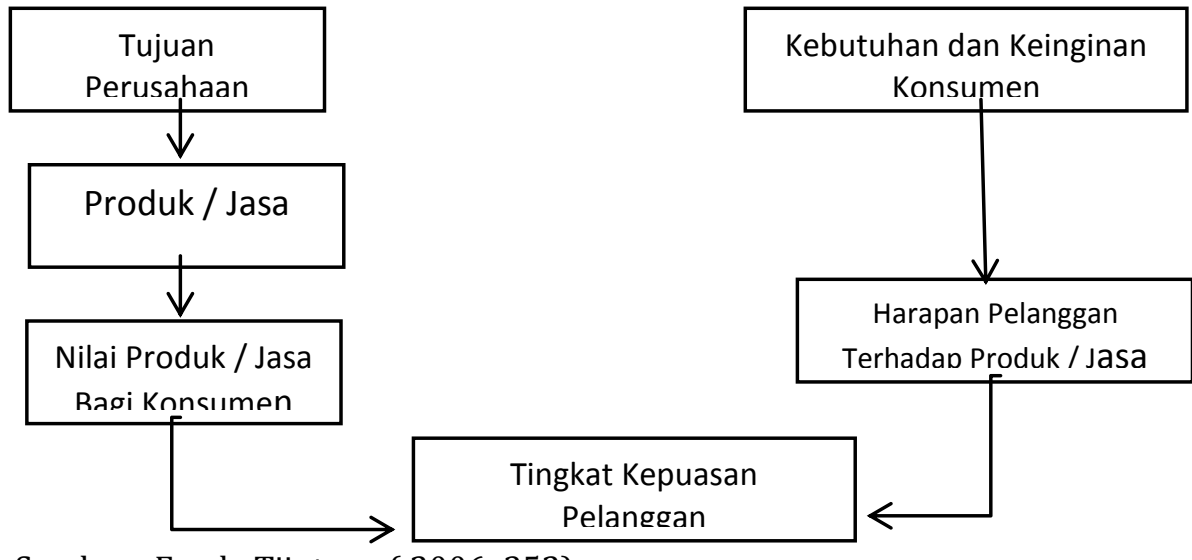

Sumber : Fandy Tjiptono ( 2006; 352)

\section{Mengukur Kepuasan}

Kepuasan konsumen merupakan keadaan dimana kebutuhan, harapan dan keinginan bertemu pada satu titik untuk dipenuhi. Terdapat beberapa cara mengukur kepuasan konsumen, menurut Kotler dalam Tjiptono (2006;370) cara - cara tersebut yaitu :

1. Sistem keluhan dan saran.

2. Survey kepuasan pelanggan.

3. Pembeli bayangan.

4. Analisis pelanggan yang beralih.

\section{Teknik Mengukur Kepuasan Pelanggan}

Purwadi (2000; 284) menyatakan bahwa unsur kepuasan konsumen dapat dikategorikan menjadi lima faktor yaitu :
1. Silent Service
2. Image
3. Proactive Service
4. Quality Product/Service
5. Pricing 


\section{Metode Customer Satisfaction Index (CSI)}

Metode Customer Satisfaction Index (CSI) merupakan suatu indeks yang menentukan tingkat kepuasan konsumen secara menyeluruh dengan pendekatan yang memperhitungkan tingkat kepentingan dan kinerja dari atribut-atribut yang diukur.

\section{Strategi Pemasaran}

Menurut Barney dalam Aisyah (2007;4) strategi sebagai teori perusahaan tentang bagaimana bersaing dengan sukses. Sedangkan pemasaran merupakan sebagai usaha untuk menciptakan dan menyerahkan suatu standar kehidupan. Dalam makna luasnya, pemasaran dinyatakan sebagai kegiatan manusia yang diarahkan untuk memenuhi dan memuaskan kebutuhan dan keinginan melalui proses pertukaran (Assauri, 2011 ; 198). Marketing is a particular way of thinking through difference, to create difference through others for the benefit of an organization (Hill, 2010;27).

Menurut Reid dan Bojanic dalam Pertiwi, (2011) menyatakan ada empat konsep dalam memformulasi strategi pemasaran dalam hubungannya dengan pengelolaan produk baru yang sudah ada pada pasar yang baru, yaitu :

1. Strategi penetrasi pasar

2. Strategi pengembangan produk baru

3. Strategi pengembangan pasar

\section{Penjualan Langsung Berjenjang / MLM}

Sreekumar (2007) menyatakan konsep terori MLM sebagai berikut "Concept selling mostly uses Personal selling as a tool where the sales person depends on referrals. If he is successful in generating referrals from each customer, this will have a multiplication effect in the client database, in a very short time. This concept is knowingly or unknowingly employed by many of the successful salesmen irrespective of the product or industry. In $M L M$, technically, the promotion expenses on advertising, channel margins etc is distributed among the members as incentives."

\section{Gambar 2. 4 Model Jaringan Bisnis Menurut Sreekumar}

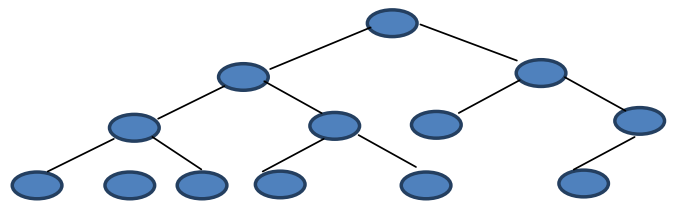

Sumber : Journal of International Marketing Conference on Marketing \& Society, 8-10 April, 2007, IIMK

\section{Penjualan Langsung Berjenjang Syariah}

Menurut Kuswara $(2005 ; 86)$ PLBS erdapat 5 ciri - ciri PLBS yang baik sebagai berikut :

1. Pendaftaran; Biaya pendaftaran haruslah relatif tidak terlalu mahal dan masuk akal.

2. Support Syste; Terdapat pelatihan yang dilakukan oleh grup atau tim atau oleh perusahaan langsung yang dilakukan secara teratur. 
110 |Ariyono \& Hakim:Analisis Kepuasan Jamaah Umroh Terhadap Penerapan Sistem Pemasaran Penjualan Langsung...

3. Perusahaan; Perusahaannya harus jelas, yakni dapat berarti badan hukumnya ada, alamatnya juga diketahui secara pasti, kepemilikan gedung.

4. Business Plan; Business Plan harus jelas, realistis, transparan dan mudah dipahami serta diaplikasikan.

5. Produk; Memiliki produk yang dijual, harganya terjangkau dan berkualitas.

\section{METODE PENELITIAN}

Jenis penelitian yang digunakan peneliti adalah penelitian deskriptif. Dan menggunakan pendekatan survey. Populasi dari penelitian ini adalah jamaah umrah PT. Arminareka Perdana sebesar 30.320 jamaah umrah. Sampel penelitian ini sejumlah 100 responden dengan teknik stratified random sampling. Data yang terkumpul akan diolah menggunakan metode Customer Satisfaction Index (CSI) berdasarkan tiap variable yaitu silent service, image, proactive service, quality product dan pricing. Data yang telah ditetapkan untuk diolah akan diberi skor untuk setiap jawaban yang diberikan responden sesuai prosedur yang ditetapkan.

Tabel 3. 1 Customer Satisfaction Index

\begin{tabular}{|l|l|l|l|}
\hline \multirow{2}{*}{ Atribut } & Skoring $(X)$ & Responden $(Y)$ & Skor Akhir $(S)$ \\
\cline { 2 - 4 } & Skala 1-5 & & S $X^{*} Y$ \\
\hline Sangat Puas & 5 & & \\
\hline Puas & 4 & & \\
\hline Cukup Puas & 3 & & \\
\hline Tidak Puas & 2 & & Total $(S)=(T)$ \\
\hline Sangat Tidak Puas & 1 & & \\
\hline Skor Total & & Total $=Y$ & \\
\hline Skor Tertinggi & & $5 Y$ & $Y$ \\
\hline Skor Terendah & & $Y$ & \\
\hline
\end{tabular}

\section{HASIL DAN ANALISIS}

\section{Analisis Kepuasan Jamaah}

Setelah diketahui latar belakang responden jamaah umrah PT. Arminareka Perdana, berikut ini analisa kepuasan jamaah umrah yang diperoleh dari 103 orang responden. Berikut ini instrumen penelitian yang digunakan dalam membuat pertanyaan tentang kepuasan jamaah umrah. Berikut analisa kepuasan pelanggan secara spesifik berdasarkan beberapa variabel :

\section{Tingkat Kepuasan Terhadap Variabel Silent Service}

Tabel 4. 1 Tingkat Kepuasan Terhadap Variabel Silent Service

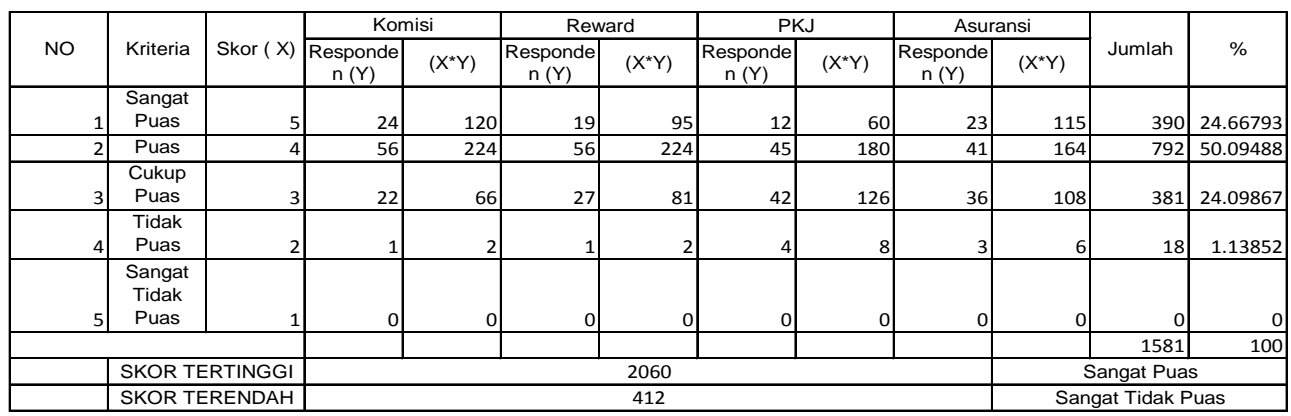

Dari tabel diatas dapat kita lihat bahwa tingkat kepuasan responden terhadap variabel silent service memiliki skor sebesar 1581 dari total skor tertinggi sebesar 2060. 
Jurnal Ekonomi dan Perbankan Syariah

Vol. 3. No.2, 0ctober 2015: 105-116, ISSN (cet): 2355-1755

Hal ini menandakan tingkat kepuasan jamaah sebesar $76.74 \%$ terhadap variabel silent service tergolong puas.

\begin{tabular}{llllll}
0 & $20 \%$ & $40 \%$ & $60 \%$ & $80 \%$ & $100 \%$ \\
\hline STP & TP & CP & P & SP & \\
& $\mathbf{7 6 . 7 4 \%}$ & \\
$\longrightarrow$
\end{tabular}

\section{Tingkat Kepuasan Terhadap Variabel Image}

Tabel 4. 2 Tingkat Kepuasan Terhadap Variabel Image

\begin{tabular}{|c|c|c|c|c|c|c|c|c|}
\hline \multirow[b]{2}{*}{ NO } & \multirow[b]{2}{*}{ Kriteria } & \multirow[b]{2}{*}{ Skor ( X) } & \multicolumn{2}{|c|}{ Das Hukum } & \multicolumn{2}{|c|}{ legalitas } & \multirow[b]{2}{*}{ Jumlah } & \multirow[b]{2}{*}{$\%$} \\
\hline & & & $\begin{array}{c}\text { Responde } \\
n(Y)\end{array}$ & $\left(X^{*} Y\right)$ & $\begin{array}{c}\text { Responde } \\
\mathrm{n}(\mathrm{Y})\end{array}$ & $\left(X^{*} Y\right)$ & & \\
\hline 1 & $\begin{array}{c}\text { Sangat } \\
\text { Puas }\end{array}$ & 5 & 44 & 220 & 47 & 235 & 455 & 50,78125 \\
\hline 2 & Puas & 4 & 52 & 204 & 45 & 180 & 384 & 42,85714 \\
\hline 3 & $\begin{array}{l}\text { Cukup } \\
\text { Puas }\end{array}$ & 3 & 8 & 24 & 11 & 33 & 57 & 6,361607 \\
\hline 4 & $\begin{array}{l}\text { Tidak } \\
\text { Puas }\end{array}$ & 2 & 0 & 0 & 0 & 0 & 0 & 0 \\
\hline 5 & $\begin{array}{c}\text { Sangat } \\
\text { Tidak } \\
\text { Puas } \\
\end{array}$ & 1 & 0 & 0 & 0 & 0 & 0 & 0 \\
\hline & & & & & & & 896 & 100 \\
\hline & \multicolumn{2}{|c|}{ SKOR TERTINGGI } & \multicolumn{4}{|c|}{1030} & \multicolumn{2}{|c|}{ Sangat Puas } \\
\hline & \multicolumn{2}{|c|}{ SKOR TERENDAH } & \multicolumn{4}{|c|}{206} & \multicolumn{2}{|c|}{ Sangat Tidak Puas } \\
\hline
\end{tabular}

Dari data tabel diatas dapat dilihat bahwa tingkat kepuasan responden terhadap variabel image mencapai skor 896 dari 1030 dari skor maksimum. Dengan demikian, dapat disimpulkan bahwa tingkat kepuasan responden terhadap variabel image sebesar $86,99 \%$ tergolong sangat puas.

\begin{tabular}{cccccc}
0 & $20 \%$ & $40 \%$ & $60 \%$ & $80 \%$ & $100 \%$ \\
\hline STP TP & CP & P $\begin{array}{c}\text { SP } \\
\mathbf{8 6 , 9 9 \%}\end{array}$ & \\
& & $\longrightarrow$
\end{tabular}

\section{Tingkat Kepuasan Terhadap Variabel Proactive Service}

Tabel 4. 3 Tingkat Kepuasan Terhadap Variabel Proactive Service

\begin{tabular}{|c|c|c|c|c|c|c|c|c|}
\hline \multirow[b]{2}{*}{ NO } & \multirow[b]{2}{*}{ Kriteria } & \multirow[b]{2}{*}{ Skor $(X)$} & \multicolumn{2}{|c|}{ Ketepatan Waktu Komis } & \multicolumn{2}{|c|}{ Starter Kit } & \multirow[b]{2}{*}{ Jumlah } & \multirow[b]{2}{*}{$\%$} \\
\hline & & & \begin{tabular}{|c|} 
Responde \\
$n(Y)$
\end{tabular} & $\left(X^{*} Y\right)$ & $\begin{array}{c}\text { Responde } \\
n(Y)\end{array}$ & $\left(X^{*} Y\right)$ & & \\
\hline 1 & $\begin{array}{c}\text { Sangat } \\
\text { Puas }\end{array}$ & 5 & 8 & 40 & 5 & 25 & 65 & 9,984639 \\
\hline 2 & Puas & 4 & 30 & 120 & 26 & 104 & 224 & 34,4086 \\
\hline 3 & $\begin{array}{l}\text { Cukup } \\
\text { Puas }\end{array}$ & 3 & 45 & 135 & 45 & 135 & 270 & 41,47465 \\
\hline 4 & $\begin{array}{l}\text { Tidak } \\
\text { Puas } \\
\end{array}$ & 2 & 18 & 36 & 27 & 54 & 90 & 13,82488 \\
\hline 5 & $\begin{array}{c}\text { Sangat } \\
\text { Tidak } \\
\text { Puas }\end{array}$ & 1 & 2 & 2 & 0 & 0 & 2 & 0,30722 \\
\hline \multicolumn{3}{|c|}{ Total } & 103 & 333 & 103 & 318 & 651 & 100 \\
\hline & \multicolumn{2}{|c|}{ SKOR TERTINGGI } & \multicolumn{4}{|c|}{1030} & \multicolumn{2}{|c|}{ Sangat Puas } \\
\hline & \multicolumn{2}{|c|}{ SKOR TERENDAH } & \multicolumn{4}{|c|}{206} & \multicolumn{2}{|c|}{ Sangat Tidak Puas } \\
\hline
\end{tabular}


112 | Ariyono \& Hakim:Analisis Kepuasan Jamaah Umroh Terhadap Penerapan Sistem Pemasaran Penjualan Langsung...

Dari data tabel diatas dapat dilihat bahwa tingkat kepuasan responden terhadap variabel proactive service mendapati skor sebesar 651 dari total skor tertinggi yaitu 1030. Artinya tingkat kepuasan untuk variabel proactive service ini sebesar $60,2 \%$ tergolong kurang puas.

\begin{tabular}{llllll|l}
0 & $20 \%$ & $40 \%$ & $60 \%$ & $80 \%$ & $100 \%$ & \\
\hline STP & TP & $\begin{array}{c}\text { CP } \\
\mathbf{6 0 , 2 \%}\end{array}$ & P & SP & & \\
& & & &
\end{tabular}

\section{Tingkat Kepuasan Terhadap Variabel Quality Product}

Tabel 4. 4 Tingkat Kepuasan Terhadap Variabel Quality Product

\begin{tabular}{|c|c|c|c|c|c|c|c|c|c|c|c|c|}
\hline \multirow[b]{2}{*}{ NO } & \multirow[b]{2}{*}{ Kriteria } & \multirow[b]{2}{*}{ Skor (X) } & \multicolumn{2}{|c|}{ Umrah dan PLBS } & \multicolumn{2}{|c|}{ Kemitraan } & \multicolumn{2}{|c|}{ Paket Umrah } & \multicolumn{2}{|c|}{ Teknologi } & \multirow[b]{2}{*}{ Jumlah } & \multirow[b]{2}{*}{$\%$} \\
\hline & & & \begin{tabular}{|c|} 
Respond \\
en $(Y)$
\end{tabular} & $\left(X^{*} Y\right)$ & $\begin{array}{c}\text { Respond } \\
\text { en }(Y)\end{array}$ & $\left(X^{*} Y\right)$ & $\begin{array}{c}\text { Responden } \\
(\mathrm{Y})\end{array}$ & $\left(X^{*} Y\right)$ & $\begin{array}{c}\text { Respond } \\
\text { en }(\mathrm{Y})\end{array}$ & $\left(X^{*} Y\right)$ & & \\
\hline 1 & $\begin{array}{c}\text { Sangat } \\
\text { Puas }\end{array}$ & 5 & 29 & 145 & 31 & 155 & 26 & 130 & 17 & 85 & 515 & 31,63391 \\
\hline 2 & Puas & 4 & 58 & 232 & 56 & 224 & 61 & 244 & 32 & 128 & 828 & 50,85995 \\
\hline 3 & $\begin{array}{l}\text { Cukup } \\
\text { Puas }\end{array}$ & 3 & 16 & 48 & 16 & 48 & 15 & 45 & 35 & 105 & 246 & 15,11057 \\
\hline 4 & $\begin{array}{l}\text { Tidak } \\
\text { Puas }\end{array}$ & 2 & 0 & 0 & 0 & 0 & 1 & 2 & 18 & 36 & 38 & 2,334152 \\
\hline 5 & $\begin{array}{l}\text { Sangat } \\
\text { Tidak } \\
\text { Puas }\end{array}$ & 1 & 0 & 0 & 0 & 0 & 0 & 0 & 1 & 1 & 1 & 0,061425 \\
\hline \multicolumn{3}{|c|}{ TOTAL } & 103 & 425 & 103 & 427 & 103 & 421 & 103 & 355 & 1628 & 100 \\
\hline \multicolumn{3}{|c|}{ SKOR TERTINGGI } & \multicolumn{8}{|c|}{2060} & \multicolumn{2}{|c|}{ Sangat Puas } \\
\hline \multicolumn{3}{|c|}{ SKOR TERENDAH } & \multicolumn{8}{|c|}{412} & \multicolumn{2}{|c|}{ Sangat Tidak Puas } \\
\hline
\end{tabular}

Data tabel diatas menunjukkan bahwa tingkat kepuasan responden terhadap variabel quality product mendapati skor sebesar 1628 dari total skor tertinggi yaitu 2060 . Artinya tingkat kepuasan untuk variabel quality product ini sebesar 79,02\% dari tingkat yang diharapkan sebesar $100 \%$ dan ini menandakan bahwa responden menyatakan puas terhadap variabel quality product di PT. Arminareka Perdana.

\begin{tabular}{llllll}
0 & $20 \%$ & $40 \%$ & $60 \%$ & $80 \%$ & $100 \%$ \\
\hline STP & TP & CP & P & SP \\
& & $79,02 \%$
\end{tabular}

\section{Tingkat Kepuasan Terhadap Variabel Pricing}

Tabel 4. 5 Tingkat Kepuasan Terhadap Variabel Pricing

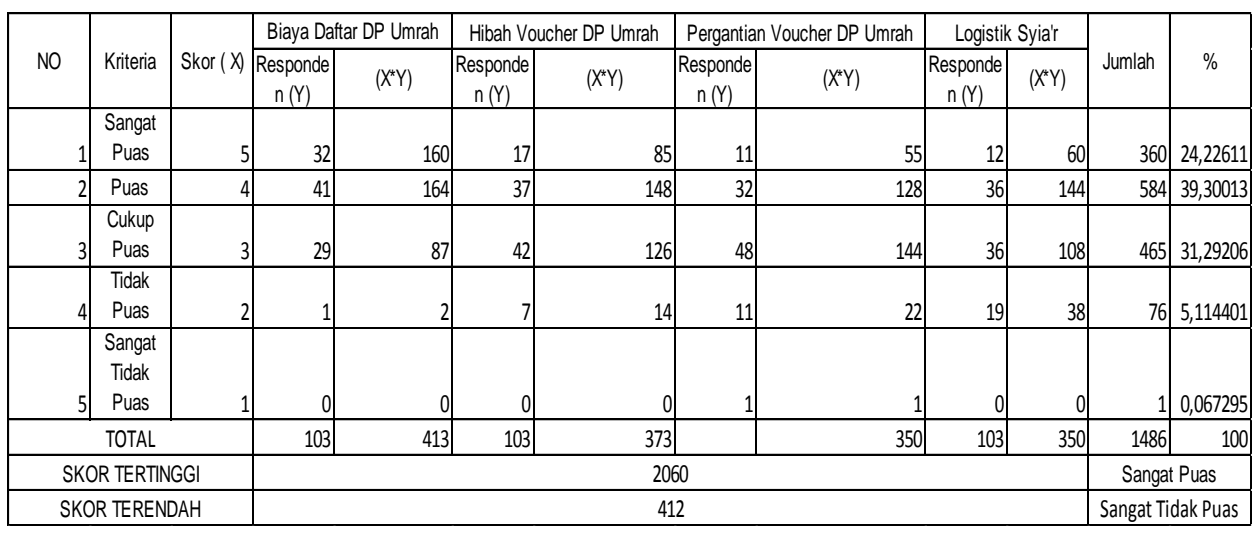


Data tabel diatas menunjukkan bahwa tingkat kepuasan responden terhadap variabel pricing mendapati skor sebesar 1486 dari total skor tertinggi yaitu 2060. Artinya tingkat kepuasan untuk variabel pricing ini sebesar 72,14\% dari tingkat yang diharapkan sebesar $100 \%$ dan ini menandakan bahwa responden menyatakan puas terhadap variabel pricing di PT. Arminareka Perdana.

\begin{tabular}{llllll}
0 & $20 \%$ & $40 \%$ & $60 \%$ & $80 \%$ & $100 \%$ \\
\hline STP & TP & CP & P & SP & \\
& $72,14 \%$ &
\end{tabular}

\section{B. Analisis Kepuasan Secara Keseluruhan}

Tabel 4. 6 Kepuasan Responden PT. Arminareka Perdana

\begin{tabular}{|c|c|c|c|c|c|c|}
\hline & VARIABEL & INDIKATOR & $\begin{array}{c}\text { SKOR } \\
\text { TERTINGGI } \\
\end{array}$ & $\begin{array}{c}\text { SKOR } \\
\text { TERENDAH }\end{array}$ & $\begin{array}{c}\text { SKOR } \\
\text { KENYATAAN }\end{array}$ & $\begin{array}{l}\text { KEPUASAN } \\
\text { RESPONDEN }\end{array}$ \\
\hline \multirow{4}{*}{1} & \multirow{4}{*}{$\begin{array}{l}\text { SILENT } \\
\text { SERVICE }\end{array}$} & 1. Komisi & 515 & 103 & 412 & 0,8 \\
\hline & & 2.reward & 515 & 103 & 402 & 0,780582524 \\
\hline & & 3.PKJ & 515 & 103 & 374 & 0,726213592 \\
\hline & & 4. Asuransi Perlindungan Jamaah & 515 & 103 & 393 & 0,763106796 \\
\hline \multirow{2}{*}{2} & \multirow{2}{*}{ IMAGE } & 1. Dasar Hukum atau Fatwa & 515 & 103 & 448 & 0,869902913 \\
\hline & & 2. LegalitasPerusahaan & 515 & 103 & 448 & 0,869902913 \\
\hline \multirow[b]{2}{*}{3} & \multirow{2}{*}{$\begin{array}{l}\text { PROACTIVE } \\
\text { SERVICE }\end{array}$} & 1. Ketepatan Waktu Pencairan Komisi & 515 & 103 & 333 & 0,646601942 \\
\hline & & $\begin{array}{l}\text { 2.ketepatan Waktu Souvenir diterima } \\
\text { oleh jamaah non JABODETABEK }\end{array}$ & 515 & 103 & 318 & 0,617475728 \\
\hline \multirow{4}{*}{4} & \multirow{4}{*}{$\begin{array}{l}\text { QUALITY } \\
\text { PRODUCT }\end{array}$} & 1. Persepsi Jamaah Umrah & 515 & 103 & 425 & 0,825242718 \\
\hline & & 2. Paket Kemitraan Usaha & 515 & 103 & 427 & 0,829126214 \\
\hline & & 3. Paket Keberangkatan Umrah & 515 & 103 & 421 & 0,817475728 \\
\hline & & 4. Teknologi & 515 & 103 & 355 & 0,689320388 \\
\hline \multirow{4}{*}{5} & \multirow{4}{*}{ PRICING } & 1. Biaya daftar umrah / DP umrah & 515 & 103 & 413 & 0,801941748 \\
\hline & & 2.Biaya hibah voucher DP umrah & 515 & 103 & 373 & 0,724271845 \\
\hline & & $\begin{array}{l}\text { 3. Biaya pergantian voucher rusak / } \\
\text { hilang }\end{array}$ & 515 & 103 & 350 & 0,67961165 \\
\hline & & 4. Biaya logistik & 515 & 103 & 350 & 0,67961165 \\
\hline
\end{tabular}

Tabel diatas menjelaskan skor kenyataan dari setiap indikator yang dimiliki oleh setiap variabel sebagai berikut :

1. Variabel silent service

Variabel ini memperoleh nilai kepuasan sebesar 0,76 dari 1,00 yang diharapkan atau dikatakan puas. Hal ini dikarenakan responden merasa puas pada setiap indikator indikator di variabel silent service terutama pada indikator komisi dengan skor perolehan sebesar 0,78. Responden merasa puas dengan komisi yang diberikan perusahaan sebesar Rp 1.500.000,00 per 1 orang yang telah direferensikan oleh responden.

2. Variabel image 
Responden merasa sangat puas dengan ketersediaan legalitas perusahaan serta adanya fatwa DSN - MUI yang digunakan sebagai pedoman dalam menerapkan sistem Penjualan Langsung Berjenjang Syariah (PLBS) pada PT. Arminareka Perdana. Variabel ini memperoleh nilai kenyataan kepuasan yaitu 0,86 . Kedua indikator pada variabel image yang memperoleh nilai kenyataan kepuasan yang sama yaitu sebesar 0,86 .

3. Variabel proactive Service

Responden merasa cukup puas dengan variabel proactive service pada sistem PLBS di PT. Arminareka Perdana dengan skor kenyataan kepuasan sebesar 0,60. Hal ini dikarenakan ketepatan waktu pencairan komisi yang sering telat serta ketepatan waktu estimasi yang diberikan pihak perusahaan kepada responden yang tidak sesuai. Indikator pada variabel ini yaitu ketepatan pencairan komisi memperoleh skor kenyataan kepuasan sebesar 0,64 dan indikator ketepatan waktu penerimaan paket souvenir memperoleh skor kenyataan kepuasan sebesar 0,61 .

4. Variabel quality product

Responden merasa puas dengan variabel quality product pada perusahaan PT. Arminareka Perdana yang memperoleh skor kepuasan kenyataan sebesar 0,79. Indikator pada variabel ini berupa paket kemitraan usaha memperoleh skor kenyataan kepuasan sebesar 0,82. Hal ini dikarenakan responden merasa bahwa paket kemitraan usaha layak digunakan sebagai jalan untuk meningkatkan taraf hidup dan mempermudah berangkat umrah.

5. Variabel pricing

Responden merasa puas dengan variabel pricing ini dengan skor kenyataan sebesar 0,72. Indikator pada variabel ini yaitu biaya daftar Umrah atau DP umrah memperoleh skor tertinggi sebesar 0,80. Hal ini dikarenakan hanya dengan membayar DP umrah, responden telah mendapat hak usaha

\section{SIMPULAN}

Tujuan dari penelitian ini adalah untuk mengetahui kinerja perbankan syariah di Indonesia dan Malaysia dan merangking bank syariah berdasarkan Maqashid Indeks yang dikembangkan oleh Mohammed dkk. Untuk mengetahui kinerja perbankan syariah di kedua negara, penulis melakukan perhitungan terhadap 4 bank syariah dari masingmasing negara berdasarkan aset terbesar selama tahun 2011-2014. Empat bank syariah baik di Indonesia terdiri dari BSM, BMI, BRIS dan BNIS. Sementara itu, empat dari Malaysia adalah CIMBiB, BIMB, MIB dan RHBiB. Berdasarkan hasil perhitungan kinerja perbankan syariah berdasarkan Maqashid Indeks di Indonesia secara keseluruhan di tahun 2011-2014. Hasil menunjukkan bahwa BMI memilki kinerja terbaik dengan capaian nilai sebesar $15.12 \%$ dan kinerja terendah 7.02\% diperoleh CIMBiB. Selanjutnya, dibawahnya secara berutan BRIS, BSM, RHBiB, MIB dan BIMB dengan nilai $12.49 \%$, $12.08 \%, 10.47 \%, 10.37 \%, 9.73 \%, 8.50 \%$ dan 7.02\%. Dengan demikian, kinerja perbankan syariah di Indonesia lebih baik dibandingkan dengan perbankan syariah di Malaysia. 
Jurnal Ekonomi dan Perbankan Syariah

Vol. 3. No.2, 0ctober 2015: 105-116, ISSN (cet): 2355-1755

\section{DAFTAR PUSTAKA}

Badan Pusat Statistik. (2014). Statistik Indonesia (Statistical Yearbook of Indonesia). Jakarta: BPS.

Badreldin, A. M. (2009). Measuring the Performance of Islamic Bank by Adapting Conventional Ratios. 1-28.

Bank Indonesia. (2012, 2013, 2014). Annual Report. Retrieved November 11, 2014, from www.bi.go.id.

Bank Islam Malaysia Berhad. (2011, 2012, 2013, 2014). Annual Report. Retrieved November 23, 2014, from www.bankislam.com.my.

Bank Muamalat Indonesia. (2011, 2012, 2013, 2014). Annual Report. Retrieved November 21, 2014, from www.muamalatbank.com.

Bank Negara Indonesia Syariah. (2011, 2012, 2013, 2014). Annual Report. Retrieved November 21, 2014, from www.bnisyariah.co.id.

Bank Negara Malaysia. (2012, 2013, 2014). Annual Report. Retrieved November 11, 2014 , from http://www.bnm.gov.my/.

Bank Rakyat Indonesia Syariah. (2011, 2012, 2013, 2014). Annual Report. Retrieved November 21, 2014, from www.bnisyariah.co.id.

Bank Syariah Mandiri. (2011, 2012, 2013, 2014). Annual Report. Retrieved November 21, 2014, from www.syariahmandiri.co.id.

Bedoui, M. H. (Januari 2012). Shari'a-based ethical performance measurement framework. 1-12.

Chapra, M. U. (2000). Sistem Moneter Islam. Jakarta: Gema Insasi Press \& Tazkia Press.

CIMB Islamic Bank Berhad. (2011, 2012, 2013, 2014). Annual Report. Retrieved November 23, 2014, from www.cimbislamic.com.

Ernest, \& Young. (2013-2014). World Islamic Banking Competitivness Report. The Transition Begin, 1-84.

Fazlulrrahman. (1984). Islam. Bandung: Penerbit Pustaka.

Ginanjar, R. D. (2013). Pengaruh Non Performing Financing terhadap Profitabilitas Bank Syariah (Studi pada Perbankan Syariah yang terdaftar di Bursa Efek Indonesia.

Hameed, S., Pramono, S. d., Nazli, M., \& dkk. (2004 ). Alternative Disclosure and Performance Measures for Islamic Banks. Working Paper: IIUM, 1-37.

Hawary, D. E., Grais, W., \& Iqbal, Z. (2004). Regulating Islamic financial institutions: The nature of the regulated. World Bank Policy Research Working Paper, 1-49.

Iqbal, Z. (1997, Juni). Islamic Financial System. Finance \& Development, 42-45.

(2013). Islamic Finance Industry Outperfomrs. Malaysia's Islamic Finance Centre.

Ismail, N. (2011). Maqashid Syariah Dalam Ekonomi Islam. Jakarta: Gema Insani Press.

Kuppusamy, M. d. (2010 ). Measurement of Islamic Banks Performance Using a Shariah Conformity Measurement of Islamic Banks Performance Using a Shariah Conformity and Profitablity Model. Jurnal Review of Islamic Economics, 13 , 35-48.

Luqman, Jazil, T., \& dkk. (2013). The Performance Selected Malaysian and Indonesian Islamic Bank based on the Maqashid Al-Shari'ah Approach. Unpublished, 1-24.

Malaysia International Islamic Finance Centre. (2013). Islamic Finance Industry Outperforms In 2013. Kuala Lumpur: INCEIF.

Maybank Islamic Berhad. (2011, 2012, 2013, 2014). Annual Report. Retrieved November 23, 2014, from www.maybankislamic.com.my.

Mohammed, M. O., \& Taib. (2009). Testing the Performance Measures Based on Maqasid al-Shari'ah (PMMS) 24 Model Selected Islamic and Conventional Banks. 1-15.

Mohammed, M. O., Razak, D. A., \& Taib, F. M. (2008). The Performance Measures of Islamic Banking Based on the Maqasid Framework. Paper of IIUM International Accounting Conference (INTAC IV) held at Putra Jaya Marroitt, 1-17. 
116 | Ariyono \& Hakim:Analisis Kepuasan Jamaah Umroh Terhadap Penerapan Sistem Pemasaran Penjualan Langsung...

Purwanda, E., \& Muttaqien, Z. (2012). Model Pengembangan SDM Industri Perbankan Syariah di indoenesia. Forum Riset Perbankan Syariah $V$, 1-29.

RHB Islamic Bank Berhad. (2011, 2012, 2013, 2014). Annual Report. Retrieved November 23, 2014, from www.rhbislamicbank.com.my.

Shaukat, M. (2008). The Recent Financial Growth of Islamic Banks and Their Fulfilment of Maqasid al-Shariah Gap Analysis. Working jurnal INCEIF Malasyia.

Taufik, M., \& Nugraha, H. F. (2012). Model Penilaian Tingkat Kesehatan Perbankan Syariah: Implementasi Maqashid Indeks di Indonesia dan Yordania. Paper Forum Riset Perbankan Syariah, 1-32.

Yuliani, S. (2012). Analisis Kinerja Keuangan Terhadap Kinerja Sosial Bank Umum Syariah di Indonesia. 1-97.

Zahrah, M. A. (2011). Ushul Fiqih. (S. Ma'shum, Trans.) Jakarta: Pustaka Firdaus.

Zaman, R. M., \& Movassaghi, H. (2002). Interest-Free Islamic Banking: Ideals and Reality. International Journal of Finance, 2428-2442. 